\title{
Sciendo
}

DOI: $10.1515 /$ sspjce-2020-0018

\section{Reducing the carbon footprint in the foundations structures of masonry family houses}

\author{
Marcela Ondová, Adriana Eštoková, Martina Fabianová \\ Technical University of Kosice, Slovakia \\ Civil Engineering Faculty, Institute of Environmental Engineering \\ e-mail: marcela.ondova@tuke.sk
}

\begin{abstract}
Nowadays, the environmental assessment becomes more and more of interest as an additional tool for the decision-makers. The researchers in civil engineering focus on building materials, structures as well as whole buildings environmental evaluation. Analysis of the environmental impact of particular structures may be helpful for selecting building materials, with regard to the environmental performance of buildings in the early project phase. The aim of this paper is presentation of an environmental evaluation of the rarely assessed particular structures - building foundations and the analysis of the share of the building foundations to the overall environmental impact of building as well. The obtained data point to the need to include the environmental impacts of foundations when assessing the buildings, because of it is a necessary part of any type of family house. One kilogram of built-in foundations materials was responsible for emissions of $0.092 \mathrm{~kg}$ of greenhouse gases expressed by carbon dioxide $\left(\mathrm{CO}_{2}\right)$. Embodied energy was calculated as equal to $1.14 \mathrm{MJ}$ per $1 \mathrm{~kg}$ of foundations materials and $832.2 \mathrm{MJ} / \mathrm{m}^{2}$ per building floor area. The foundation materials of houses contributed to the total environmental impact of the whole buildings by, on average, 15.0 and $22.8 \%$ for embodied energy and global warming potential, respectively.
\end{abstract}

Key words: primary energy, sustainability, greenhouse gases, LCA

\section{Introduction}

Sustainability has attracted increasing attention of general public in recent years. The sustainability challenges we face today are mainly related to environmental threats [1-3]. The construction industry is an important contributor to these negative threats. The construction of buildings consumes a lot of energy, produces a lot of pollutants and solid waste, consumes renewable as well as non-renewable raw materials for the production of building materials and consumes water throughout the building's life cycle. According to UNEP-SCBI, buildings consume about $40 \%$ of the energy, $25 \%$ of the water and $40 \%$ of the resources available on Earth, while producing $30 \%$ of greenhouse gases [4]. Therefore, the construction sector is a field with immediate need for reducing environmental impacts. Many companies have found 
it advantageous to explore ways of moving beyond compliance, using pollution prevention strategies and environmental management systems, to improve their environmental performance [5]. The enforcement of energy efficient building is considered as the most successful strategy for $\mathrm{CO}_{2}$ emission reduction and energy saving during the life cycle of the building, while the application of suitable green building products plays an important role in facilitating energy efficient building promotion [6].

New environmental perceptions and sustainability approaches have led to the development of a number of environmental methods that contribute significantly to reducing environmental degradation. Monitoring the environmental performance of building materials (which can be expressed by different environmental parameters), gives us the impact of construction products and buildings on the environment during total or part of the life cycle. As a result, the degree of environmental damage can be determined. Currently, the most popular environmental impact assessment tool is method "Life Cycle Assessment" (LCA). LCA is an environmental approach that considers all the aspects of resource use and environmental releases associated with an industrial system. Specifically, it is a holistic view of environmental interactions that covers a range of activities, from the extraction of raw materials from the Earth and the production and distribution of energy, through the use, and reuse, and final disposal of a product [7]. LCA methodology is standardized in ISO14040 [8] and 14044-2006 [9] and consists of four principle steps. Nowadays, it can be used in various fields of building assessment from building material [10] and operation phase - energy consumption [11] to apartment house [12] and residential buildings [13]. When LCA is applied to a building, the product studied is the building itself, and the assessment runs in previously determined system boundaries. Because a balance is desired between practicability of the study and validity of the results, it is possible to say an LCA presents an accurate estimate of the quantities and timing of environmental impacts, it provides a solid basis for identifying the benefits of changes in the construction of a building or its operation.

The results show that over $80 \%$ of greenhouse gases emissions take place during the operational phase of buildings, when energy is used for heating, cooling, ventilation, lighting, appliances and other applications [14]. A smaller percentage of the energy consumed is for materials manufacturing and transportation, construction, maintenance renovation and demolition. The significant environmental impact, especially as a result of the high quantity of harmful materials used for building structures, is not negligible. Author McHendry [15] reported that embodied energy is between $17 \%$ and $25 \%$ of the estimated lifetime energy demands of a building. Sartori claimed that the embodied energy in materials varied between $9 \%$ and $46 \%$ of the overall energy used over the building's lifetime when dealing with low energy consumption buildings i.e. with good insulation, adequate orientation, passive conditioning, etc., and between $2 \%$ and $38 \%$ in conventional buildings [16]. Based on the available information, it is clear that, embodied energy in conventional buildings can be reduced by approximately 10-15\% through proper selection of building materials with low environmental impacts [17].

The goal of this paper was to analyse the environmental impacts of five Slovak masonry family houses paying special regard to the foundations materials. Environmental analysis was focused on the calculation of embodied energy (primary energy) and global warming potential in order to determine the share of foundation materials in the overall environmental impact of the building. 


\section{Material and methods}

Masonry family houses with commonly used building materials were selected for an evaluation of the environmental impacts of building foundations. The configurations of five assessed houses are stated in Table 1.

Table 1: Purposeful space configurations of the houses

\begin{tabular}{|l|c|c|c|c|c|}
\hline \multicolumn{1}{|c|}{ Space configuration } & $\mathrm{H} 1$ & $\mathrm{H} 2$ & $\mathrm{H} 3$ & $\mathrm{H} 4$ & $\mathrm{H} 5$ \\
\hline Total built-up area $\left[\mathrm{m}^{2}\right]$ & 192.4 & 158.7 & 148.9 & 101.9 & 461.4 \\
\hline Calculated built-up area $\left[\mathrm{m}^{2}\right]$ & 185.5 & 110.3 & 112.5 & 95.1 & 440.5 \\
\hline Total useful area $\left[\mathrm{m}^{2}\right]$ & 468.6 & 168.6 & 182.4 & 140.7 & 370.6 \\
\hline Calculated useful area $\left[\mathrm{m}^{2}\right]$ & 468.6 & 147.4 & 164.6 & 110.5 & 340.8 \\
\hline Living area $\left[\mathrm{m}^{2}\right]$ & 235.8 & 114.7 & 87.0 & 80.4 & 155.9 \\
\hline Floor area $\left[\mathrm{m}^{2}\right]$ & 518.7 & 220.6 & 220.2 & 171.1 & 440.5 \\
\hline Built-up volume $\left[\mathrm{m}^{3}\right]$ & 2393 & 612.5 & 611.6 & 636.7 & 1987 \\
\hline Heated area $\left[\mathrm{m}^{2}\right]$ & 435.0 & 138.6 & 131.7 & 110.1 & 155.9 \\
\hline Heated volume $\left[\mathrm{m}^{3}\right]$ & 1131 & 530.0 & 507.0 & 286.2 & 623.6 \\
\hline
\end{tabular}

Next Table (2) presents an overview of used building materials.

Table 2: Representation of used materials in the assessed houses - weight [kg]

\begin{tabular}{|c|c|c|c|c|c|}
\hline Groups of used materials & $\mathrm{H} 1$ & $\mathrm{H} 2$ & $\mathrm{H} 3$ & $\mathrm{H} 4$ & $\mathrm{H} 5$ \\
\hline Bulk materials & 18,144 & 2,718 & 63,684 & 882 & 117,684 \\
\hline $\begin{array}{c}\text { Reinforced concrete } \\
(0.7 \text { wt.\% of steel })\end{array}$ & 103,468 & 210,890 & 99,307 & 130,811 & 187,072 \\
\hline Ceramics & 107,877 & 34,625 & 31,207 & 152,186 & 65,744 \\
\hline Wood & 2,275 & 35,885 & 7,630 & 46,623 & 5,099 \\
\hline Lime cement plaster & 3,600 & 8,388 & 10,271 & 21,983 & 24,401 \\
\hline Gypsum materials & - & 1,275 & 1,832 & 1,053 & - \\
\hline Laminate & - & 84,841 & 576.6 & 331.2 & 300.9 \\
\hline Glass & 731.0 & 148.2 & 661.0 & 704.0 & 466.1 \\
\hline Other metals & - & 521 & 5,841 & - & 4,159 \\
\hline Mineral insulation & - & 2,561 & - & - & - \\
\hline PS insulation & 24.8 & 1,285 & 814.1 & 1,315 & 1,430 \\
\hline PVC materials & - & 270.0 & 383.8 & 62.5 & 426.0 \\
\hline$\sum$ & 236,121 & 383,398 & 222,207 & 313,990 & 406,781 \\
\hline
\end{tabular}

- Bulk materials included: gravel, sand and soil constituting a layer below the concrete foundations. Reinforced concrete, containing $0.7 \mathrm{wt}$ \% of steel, was used for horizontal structures of bond beams and girders, slabs and capping as well as pillars or staircase material.

- Concrete hollow blocks were also used as wall footings.

- Ceramics representing: ceramic bricks, blocks and tiles were used for load-bearing walls (perforated ceramic bricks for external and internal walls), partitions and floor surfaces as well as roof components (ceramic roof tiles). 
- The material group Wood included: wood and wood products used in ceilings, slant roof or shuttering and vapour barrier (OSB boards) and floor covering.

- Other metals (copper, aluminium) were used rarely, e.g. the damp proof course was constructed of bitumen-aluminium sheet.

- Mineral insulation (mineral wool, rock wool, mineral foam) was applied on facades (insulation of walls) and ceilings. PS insulation (polystyrene insulation) represented by expanded polystyrene EPS and extruded polystyrene XPS was used for thermal insulation of walls and foundation strips (XPS) or in floors on the ground (EPS). PVC materials were used for frame and sash construction (windows, doors).

- Lime cement plasters were used for interior surface covering.

- Gypsum materials including plaster, plasterboard and gypsum fiber boards were used for interior plastering or lower ceiling.

- Laminate materials represented floor coverings.

- Glass materials were applied in transparent or semi-transparent in-fill materials (as double or triple glazed windows or doors).

The houses evaluated are built on concrete slabs. Concrete, gravel, asphalt and polyvinylchloride were the most used materials in the foundations of the evaluated houses.

\subsection{Methodology}

The environmental evaluation of house foundations was based on the calculation of the environmental impacts of building materials used in five selected buildings. The overall environmental impact was calculated with aim to obtain the load of the foundations in comparison with the total building impacts. Environmental impacts were expressed in terms of two main important environmental indicators with respect to embodied energy (primary energy intensity - PEI) and embodied carbon emissions (global warming potential GWP [18].

- Primary energy indicates in general the level of depletion of natural resources within boundaries of evaluated product life cycle and is usually expressed in MJ or kWh.

- Global warming potential represents in a parallel manner to PEI the greenhouse gases emissions (GHGs) through the life cycle of the product or building. The strength of global warming potential is used to refer to $\mathrm{CO}_{2}$ emissions equivalent and measured in $\mathrm{kgCO}_{2}$ eq; this is then an equivalent to the impact category of Global warming potential. The GWP of the analysed building materials was calculated considering the data for 100-year time horizon.

Unit environmental indicators per $1 \mathrm{~kg}$ of building materials were calculated in boundaries "cradle to gate" [19]. The data used for the calculation of environmental performance of the used materials originated from a broadly used IBO database.

\section{Results and discussion}

Figure 1 presents the calculated environmental indicators (PEI and GWP) of evaluated house foundations. Embodied energy (PEI) of concrete slab foundation materials ranged from 122 to $220 \mathrm{GJ}$ and corresponded to the results reported for concrete bay (213 GJ) by Griffin et al. 
$[20]$.

\section{Environmental indicators compared to mass of foundation materials}

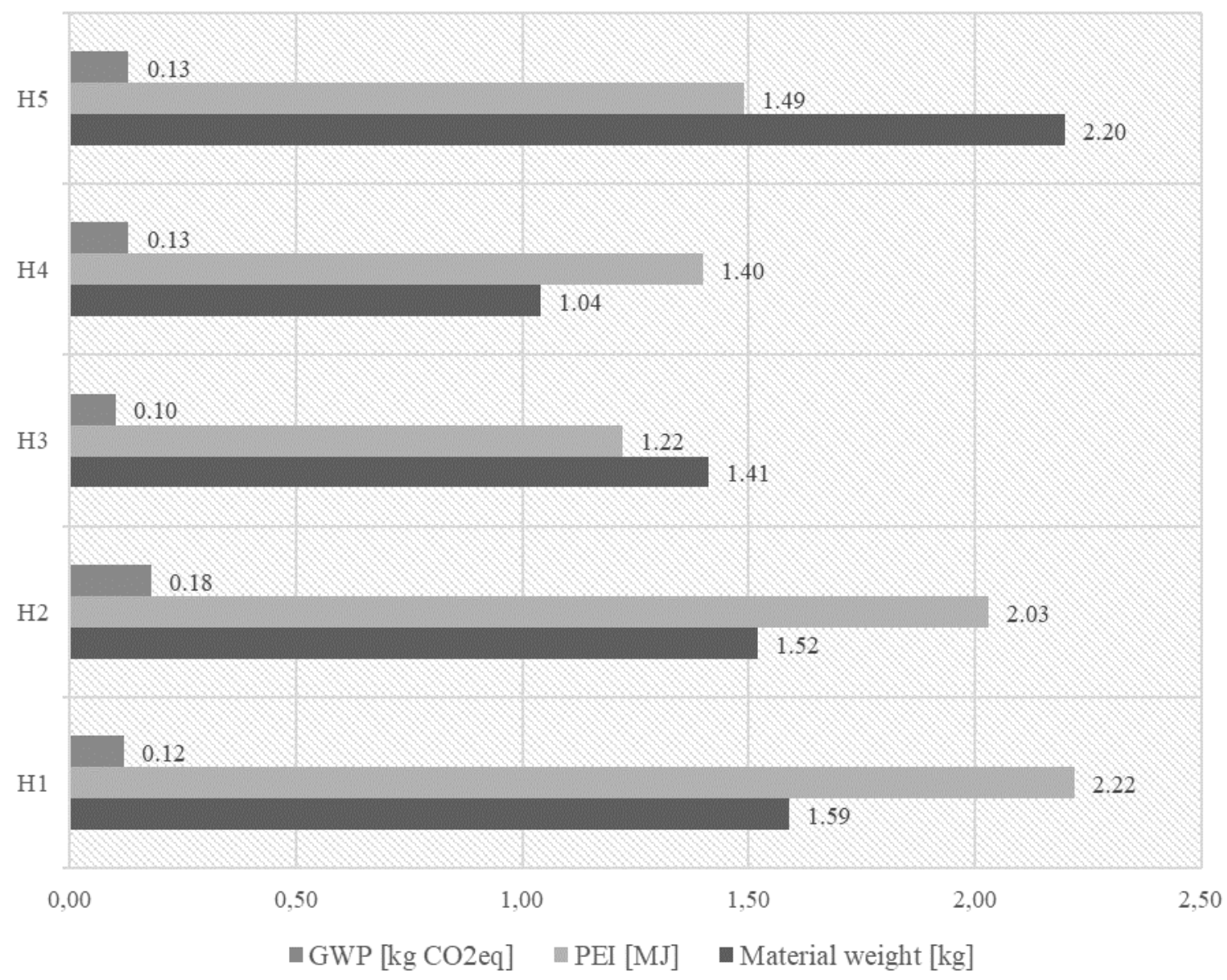

Figure 1: Environmental indicators (PEI and GWP) of house foundations (all expressed as $\times 10^{5}$ )

As seen in Figure 1, the highest PEI was not calculated for the house with the highest mass of foundation materials. In comparison, House 5 representing the highest weight of foundation building materials was responsible for PEI impact which was less than the average value (167 GJ).

Global warming potential (GWP) has been calculated in a range $0.10 \times 10^{5}-0.18 \times 10^{5} \mathrm{~kg}$ $\mathrm{CO}_{2}$ eq with an average value of $0.13 \times 10^{5} \mathrm{~kg} \mathrm{CO}_{2}$ eq. The highest and the lowest GWP values correlated to the highest and the lowest PEI values (House 3 and House 2, respectively). Environmentally suitable foundation alternatives, mentioned by Magwood and Feigin [21], reached, similarly to PEI, much lower values of embodied carbon dioxide emissions for the rammed earth tire foundations, for the stone foundations and for earth bag foundations).

Nemry et al. [22] observed that the basement (foundations), the exterior walls and floors/ceilings are important relating to the contribution of the individual construction 
elements to the environmental impacts of family houses. Interior walls, roof and windows play a minor role only.

In comparing the results of the house foundations' environmental impacts with the total environmental impacts of the whole houses, the highest contribution was observed for embodied carbon dioxide emissions. The average GWP of foundations was $1.3 \times 10^{4} \mathrm{~kg}$ $\mathrm{CO}_{2} \mathrm{eq}$, while the average GWP of the whole building was equal to $6.5 \times 10^{4} \mathrm{~kg} \mathrm{CO} \mathrm{CO}_{2} \mathrm{eq}$, which means that the foundations contribute by $1 / 5$ to total global warming potential.

The share of foundation material impacts of the overall impacts differed. Foundation materials represented: $9.0-18.1 \%$ of the embodied energy (PEI) and 12.5-28.0\% of the global warming potential (GWP) obtained for the whole buildings. The calculated values of foundations were also converted into normalised values per $1 \mathrm{~m}^{2}$ of floor area. The findings revealed that the normalised embodied energies of house foundations are in a wide range of 427.74-919.42 MJ $/ \mathrm{m}^{2}$ having an average value of $718.5 \mathrm{MJ} / \mathrm{m}^{2}$ and embodied carbon dioxide emissions (GWP) normalised per floor area ranged from 22.59 to $83.33 \mathrm{~kg} \mathrm{CO} 2 \mathrm{eq} / \mathrm{m}^{2}$. The highest normalised values of all evaluated indicators converted to floor areas have been found for House 2 and the lowest for House 1.

Based on summarising of results is obvious, that one kilogram of the foundation materials used in the study is responsible for emissions of $0.092 \mathrm{~kg} \mathrm{CO}_{2} \mathrm{eq}$ and energy for production of one kilogram of foundation is equal to $1.14 \mathrm{MJ}$. Also applies that the $\mathrm{CO}_{2}$ contribution of the concrete slab foundations can be reduced by changing the materials used, e.g. by using nonconventional materials and implementation of sustainable building materials and technologies such as a rammed earth tire foundation.

\section{Conclusion}

In this study, the environmental impacts of the foundations materials of five family houses in Slovakia were examined regarding the embodied energy of materials (PEI) and global warming potential (GWP). As can be seen from the results of the study, the calculated environmental impacts presented depend strongly on the material base used in the evaluated houses and this may vary under various conditions (geographical, climatic, economic, cultural, etc.).

The findings revealed that the share of the foundation materials of the overall environmental impact of masonry building has been the relatively high, especially on global warming potential, draws attention to the optimization of foundation materials with similar material basis.

The proposed approach of the optimalisation is focused to the harmonization between environmental and structural criteria with aim to include environmental criteria in the decisionmaking process of building design, thus fostering a more efficient use of resources throughout the life cycle of buildings and reducing the environmental impacts of construction works.

\section{Acknowledgements}

This paper has been prepared with a support of the Scientific Grant Agency of the Ministry of Education, Science, Research and Sport of the Slovak Republic and the Slovak Academy of Sciences (VEGA Grant No. 1/0648/17) and Slovak Grant Agency for Science Slovak Cultural and Education Grant Agency (Contract No. 073TUKE-4/2018). 


\section{References}

[1] Johnston, P.; Everard, M.; Santillo, D.; Robèrt, K. (2007). Reclaiming the Definition of Sustainability. Environ. Sci. Pollut. Res. 14, 60-66.

[2] Benoît, C.; Mazijn, B. Guideline for Social Life Cycle Assessment of Products; United Nations Environment Programme: Paris, France, 2009; ISBN 9789280730210.

[3] Onat, N.C.; Kucukvar, M.; Halog, A.; Cloutier, S. (2017). Systems Thinking for Life Cycle Sustainability Assessment: A Review of Recent Developments, Applications, and Future Perspectives. Sustainability 9, 706.

[4] UNEP/SETAC Life Cycle Initiative. Global Guidance Principles for Life Cycle Assessment Databases - A basis for greener processes and products - Shonan Guidance Principles. Output of the UNEP/SETAC „Global Guidance for LCA Databases“ workshop. Shonan, Japan.

[5] Curran, M. A. (2004). The status of life-cycle assessment as an environmental management tool. Env Progress 23 (4), 277-283.

[6] Huang, M., Wang, B. (2014). Evaluating green performance of building products based on gray relational analysis and analytic hierarchy process. Env Progress \& Sust Energy 33 (4), 13891395.

[7] Curran, M. A. (2016). Life Cycle Assessment.Kirk-Othmer Encyclopedia of ChemicalTechnology. 1-28.

[8] Environmental management. Life cycle assessment - Principles and framework (ISO 14040:2006)

[9] Environmental management. Life cycle assessment - Requirements and guidelines (ISO 14044:2006)

[10] Abeysundara, Y., Babel, S. (2010). A quest for sustainable materials for building elements in Sri Lanka: Foundations. Env Progress \& Sust Energy 29 (3), 370-381.

[11] Velagapudi, S., Kumar, A., Spivak, A., Franchetti, M. (2014). Comparison of pollution prevention assessments for the facilities with and without energy star certification. Env Progress \& Sust Energy 33 (4), 1366-1372.

[12] Keun, H. Y., Tae, H. K., Seung, J. R. (2015). Analysis of lifecycle $\mathrm{CO}_{2}$ reduction performance for long-life apartment house. Env Progress \& Sust Energy 34 (2), 555-556.

[13] Li, D.Z., Chenb, H.X., Huic, E.C.M., Zhanga, J.B., Lia, Q.M. (2013). A methodology for estimating the life-cycle carbon efficiency of a residential building. Build Environ 59, 448-455

[14] UNEP Sustainable Buildings \& Climate Initiatives (2009) Buildings and climate change: Summary of decision-makers, UNEP DTIE Sustainable Consumption \& Production Branch, Paris

[15] McHendry, S. (2013). The Embodied Energy and Carbon of Passive House, University of Strathclyde Engineering, Master study.

[16] Sartori, I., Hestnes, A.G. (2007). Energy use in the life-cycle of conventional and low-energy buildings: a review article. Energ Buildings 39, 249-257.

[17] Thormark, C., (2006). The effect of material choice on the total energy need and recycling potential of a building. Build Environ 41, 1019-1026.

[18] Ondova, M.; Estokova, A. (2016). Environmental impact assessment of building foundation in masonry familyhouses related to the total used building materials. Environ. Prog. Sustain. 
Energy 35, 1113-1120.

[19] Waltjen, T. (2008). Passive House - Parts Catalogue. Details for passive houses: A catalogue of ecologically rated constructions (in German), Vienna, Austria: Springer.

[20] Griffin, C.T., Reed, B., Hsu, S. (2010). Comparing the embodied energy of structural systems in buildings. Proceedings of the 1st International Conference on Structures \& Architecture (ICSA2010). Guimarães, Portugal, July 2010.

[21] Magwood, C., Feigin, J. (2014). Making better buildings: A comparative guide to sustainable construction for homeowners and contractors, 1th ed. (p. 441), Gabriola Island, Canada: New Society Publishers.

[22] Nemry, F., Uihlein, A., Colodel, C.M., Wittstock, B., Braune, A., Wetzel, C., Hasan, I., Niemeier, S., Frech, Y., Kreißig, J., Gallon, N. (2008). Environmental improvement potentials of residential buildings (IMPRO-Building), Luxembourg: Office for Official Publications of the European Communities, European Communities. 